EESTI NSV TEADUSTE AKADEEMIA TOIMETISED. 21. KÖDE

KEEMIA * GEOLOUGIA. 1972, NR. 4

ИЗВЕСТИЯ АКАДЕМИИ НАУК ЭСТОНСКОН ССР. ТОМ 21

ХИМИЯ * ГЕОЛОГИЯ. 1972, № 4

удК 551.793

\author{
ЭЛСБЕТ ЛИИВРАНД
}

\title{
ПАЛИНОЛОГИЧЕСКАЯ ХАРАКТЕРИСТИКА И КОРРЕЛЯЦИЯ МЕЖЛЕДНИКОВЫХ ОТЛОЖЕНИЙ РАЗРЕЗА КАРУКЮЛА
}

Межморенные озерно-болотные отложения разреза Карукюла в Юго-Западной Эстонии впервые изучались К. Орвику (1941*; 1960; Орвику, Пиррус, 1965; см. рис. 1) и относились им к второму климатическому оптимуму эмского межледннковья, а позже к брёрупскому межстадиалу. В последние годы карукюлаские отложения на основании результатов определения абсолютного возраста (около $30-50$ тыс. лет) сопоставляются с интерплениглящиалом Западной Европы, каргинским межледниковьем Западной Сибири, с интерстадиальными потеплениями Плам-пойнт и Порт-толбот в Северной Америке, с брянским интерстадиалом Русской равнины, перяпохьоласким интерстадиалом Северной Финляндии (Пуннинг и др., 1967; Раукас и др., 1968; Серебрянный и др., 1969; Каяк и др., 1970), с интерстадиальным потеплением в середине ленинградского оледенения (Вигдорчик и др., 1970), с тосненским интерстадиалом (Малаховский и др., 1969; Спиридонова, 1970), с интерстадиальным потеплением неоплейстоцена (Вайтекунас, 1969) и средневалдайским межледниковьем, для характеристики которого приводятся пыльцевые зоны соминского интерстадиала (Заррина, 1970; 1971).

Как видно, в отношении стратиграфического положения разреза Карукюла среди исследователей нет единого мнения. Мало того, нет единогласия и в отношении стратиграфического ранга названных отложений: некоторые исследователи считают их межледниковыми, другие интерстадиальными. Поэтому прежде всего необходимо выяснить, в каких природных условиях формировались карукюлаские слои.

Уже давно различение межледниковых и интерстадиальных климатических условий проводилось при помощи сравнения их с климатом голоцена данной местности (Jessen, Milthers, 1928). Поэтому спорово-пыльцевые спектры голоцена также могут являться эталоном при определении стратиграфического ранга изучаемых отложений по палеоботаническим данным.

Для сравнения спорово-пыльцевых диаграмм последние должны быть построены по единому принципу. Поэтому в настоящей статье ольха исключается из состава деревьев как на карукюласких, так и на голоценовых диаграммах. В таком случае количество пыльцы широколиственных пород на диаграммах Карукюла выражается цифрой $18-35 \%$ (см. рис. 2, а также Орвику, Пиррус, 1965), что вполне сравнимо с количеством пыльцы широколиственных пород в климатическом оптимуме голоцена Юго-Западной Эстонии. Так, в болоте Нигула количество пыльцы широколиственных пород в нескольких разрезах не превышает 12 -

* Орвику К. 1941. Новые находки межледниковых и межстадиальных отложений на территории Советской Эстонии. Рукопись. 
$15 \%$ и только в одном разрезе достигает $27 \%$ (Пиррус, 1963). В болоте Пылендмаа пыльцы широколиственных пород не больше $17 \%$ (Кессел, 1963).

Широколиственные породы не являются единственными элементами термофильной флоры. В состав последних входят также лещина и ольха. Поэтому высокое содержание пыльцы ольхи (до $150 \%$ ) в разрезе Карукюла также является одним из индикаторов улучшения климатических условий. Отнесение такого большого количества пыльцы ольхи к древесной значительно уменьшает процентное участие других древесных компонентов. Этим и объясняется низкое содержание пыльцы широколиственных пород (около 7\%) на диаграмме А. Лаази (Орвику, 1960).

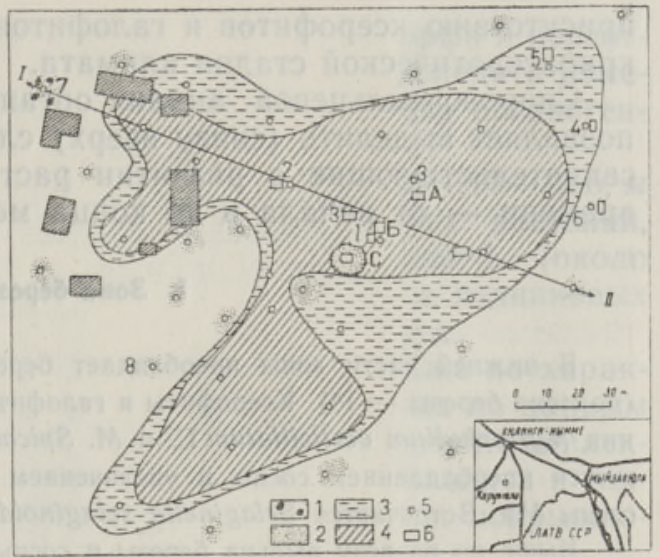

Рис. 1. Площадное распространение межморенных отложений под верхней основной мореной в Карукюла по данным К. Орвику. 1 - нижняя основная морена; 2 - песок; 3 - алеврит; 4 - сапропелит и торф; 5 - точка бурения; 6 - шурф.

Шурфы $A, B$ и $C$ описаны автором. Палинологический анализ шурфов $A$ и $B$ выполнен автором, шурфа № 3 - Р. Пиррус и шурфа № 1 - А. Лаази.

Суммарное процентное содержание термофильных элементов не является исчерпывающей характеристикой межледниковий, оно может быть даже несколько ниже, чем в голоцене. Гораздо важнее характер термофильных пород (Гричук, 1966; 1969).

Для всех без исключения межледниковых флор характерно присутствие более теплолюбивых видов, чем те, которые характеризуют голоценовую флору соответствуюшей местности. В разрезе Карукюла определены ** виды Tilia platyphyllos Scop., Trapa natans L., Picea sec. Omorica, Salvinia natans (L.) All., которые не обнаружены в голоценовых отложениях Эстонии и произрастают в настоящее время значительно южнее нашей территории.

В то же время в органогенных отложениях разреза Карукюла полностью отсутствуют такие типичные элементы ледниковой флоры, как ксерофиты и галофиты. Сохранился только реликтовый тундровый вид Betula nana L., который встречается также в голоценовых болотных отложениях и растет в настоящее время на болотах Эстонии.

Спорово-пыльцевые спектры ледниковой эпохи обнаружены только в подстилающих органогенные отложения песках и алевритах шурфов $A$ и $B$ (рис. 2), а также шурфа № 3 (Орвику, Пиррус, 1965). Пыльца березы представлена здесь преимущественно пыльцой Betula nana L. В составе трав много полыней и маревых; определены ксерофиты Ephedra sp. и Eurotia ceratoides (L.) 'C. А. М., а также галофит Salicornia herbaceae L. В песках и алевритах присутствует также переотложенная пыльца ольхи, липы, ели, сосны и древовидной березы. Судя по

** Видовые определения пыльцы и спор в разрезе Карукюла проверены в Институте географии АН СССР В. Гричуком, 3. Губониной и М. Моносзон; определения макроостатков растений выполнены Т. Колесниковой, за что автор выражает им свою благодарность. 
присутствию ксерофитов и галофитов пески и алевриты образивались в криоксеротической стадии климата.

Спорово-пыльцевой анализ органогенных слоев разреза Карукюла позволяет выделить (снизу вверх) следующие пыльцевые зоны (рис. 2), свидетельствующие о развитии растительности в течение длительного времени - от начала и до конца межледниковья.

\section{I. Зона березы и сосны}

В нижней части зоны преобладает береза, среди которой много Betula nana L. (подзона березы - $\mathrm{I}^{\mathrm{a}}$ ). Ксерофиты и галофиты отсутствуют. Встречаются водные растепия Myriophyllum verticillatum L. и M. Spicatum L. Средняя часть зоны характеризуется преобладанием сосны и увеличением количества древовидной березы (подзона сосны $\mathrm{I}^{b}$ ). Встречается Selaginella selaginoides (L.) Link.

Выше по разрезу пыльца березы и сосны обнаружена в равных количествах (подзона березы и сосны $\mathrm{I}^{\mathrm{c}}$ ). Ель и ольха, которые появились уже в предыдущей подзоне, встречаются здесь уже в значительном количестве. Широколиственные породы в пределах зоны представлены вязом $(1-5 \%)$ и дубом $(1-2 \%)$. С зоной березы и сосны связано образование нижней части сапропелита.

\section{II. Зона ели и ольхи}

Максимум ольхи достигает 150, а ели $60 \%$. Широколиственные породы представлены липой (до $3 \%$ ) и вязом (до $3 \%$ ). Встречается пыльца водяного ореха Trapa natans L. и найдены споры Osmunda. C этой зоной связано образование верхней части сапропелита.

\section{III. Зона липы, ели и ольхи с примесью пихты и граба}

Участие ели несколько уменьшается, но она остается преобладающей в пределах и этой зоны. По-прежнему много ольхи (80-120\%), лещины не больше $20 \%$. Максимум липы достигает $35 \%$. Среди липы преобладает Tilia cordata Mill; отмечены также Tilia platyphyllos Scop. и еще один не определенный вид. В составе лип много уродливых мнопоспоровых форм. Среди спор абсолютно преобладают папоротники. Присутствуют споры чистоустовых - Osmunda cinnamomea L. и еще один не определенный вид. С этой зоной связано образование хвощового торфа.

\section{IV. Зона ели, сосны и граба с примесью пихты}

Преобладающей в составе лесообразующих пород является ель (40-60\%), много сосны. Максимум граба *** достигает $6 \%$; единичными зернами представлена пихта, обнаружена пыльца Picea sec. Omorica. C этой зоной связано образование древесного торфа.

\section{V. Зона сосны и березы}

Лесообразующие породы представлены сосной $(40-60 \%)$ и березой $(25-40 \%)$, участие ели значительно уменьшилось (до 20\%). Из широколиственных пород продолжают встречаться преимущественно липа $(7 \%)$ и граб $(2 \%)$, наблюдается некоторое увеличение количества ольхи. С этой зоной связано образование верхней части древесного торфа.

**; Возможно, что низкое содержание пыльцы граба на диаграмме $A$ связано с разрушением некоторых пыльцевых зерен в процессе слишком длительной обработки перекисью водорода. 

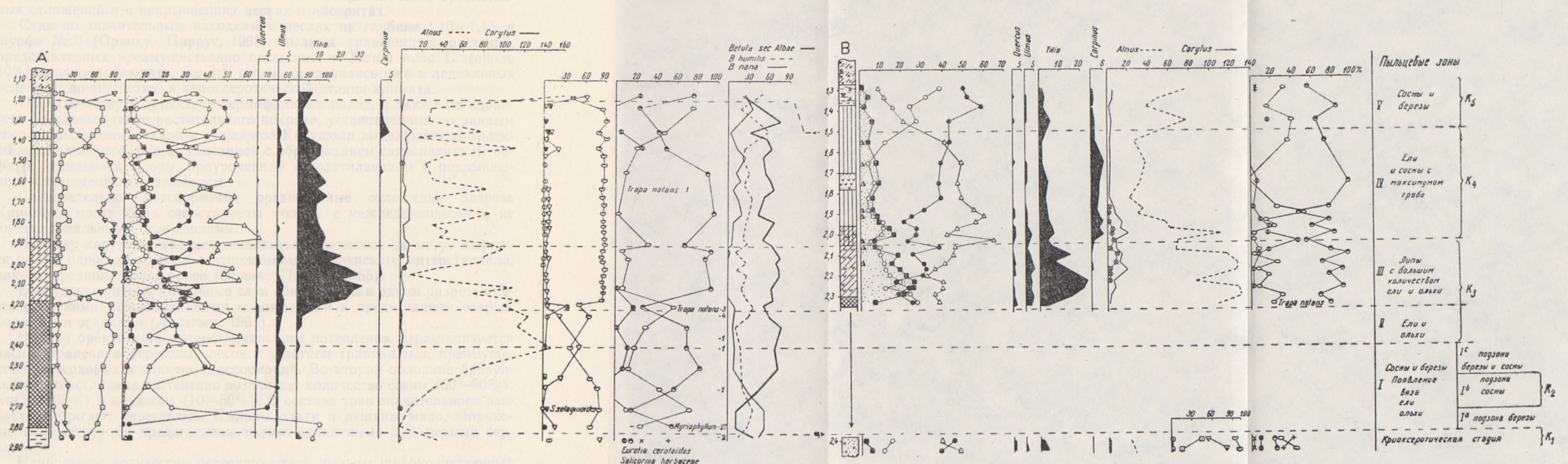

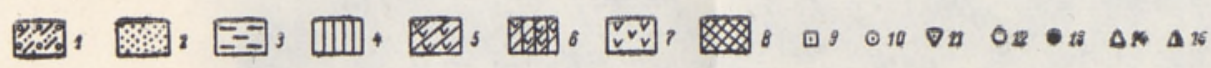

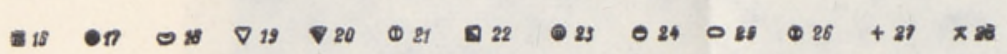

Рис. 2. Спорово-пыльцевые диаграммы межледниковых отложений разреза Карукюла.

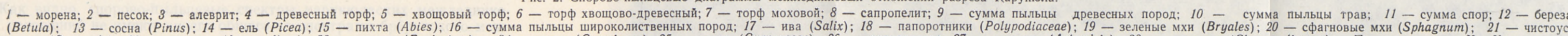

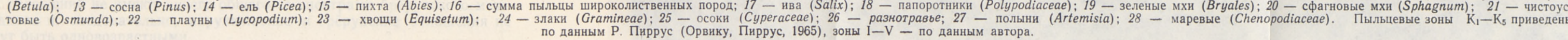


Из-за сильного разрушения верхней части древесного торфа и переотложения пыльцы и спор, особенно в шурфе $A$, трудно проследить изменения в составе пыльцы и спор, найденных в верхней части органогенных отложений и в покрывающих песках и алевритах.

Судя по значительным находкам в песках на глубине $1,10-1,15 \mu$ шурфа № 3 (Орвику, Пиррус, 1965) пыльцы травянистых растений, представленных пренмушественно полынями, и Betula nana L. (около $40 \%$ ), можно заключить, что эти пески образовались уже в ледниковых условиях, по-видимому, в криоксеротической стадии климата.

По количеству и характеру термофильных пород, а также по характеру зональных типов растительного покрова, установленных по данным спорово-пыльцевого анализа, в разрезе Карукюла выделяются комплексы межледниковой флоры, связанной с образованием сапропелита и торфа, и ледниковой флоры, приуроченной к подстилающим и покрывающим минерогенным отложениям.

Следовательно, межморенные органогенные отложения разреза Карукюла могут быть сопоставлены только с межледниковыми, а не интерстадиальными отложениями.

Поэтому карукюлаские межледниковые отложения не могут являться также одновозрастными с отложениями брёрупского интерстадиала, как это предполагалось ранее (Орвику, Пиррус, 1965).

Брёрупские интерстадиальные слои обнаружены в одном разрезе вместе с эмскими межледниковыми отложениями и представлены озерноболотными осадками (Andersen, 1961).

Начало брёрупского интерстадиального потепления характеризуется распространением березовых лесов с участием травянистых, преимущественно осоковых и злаковых, ассоциаций. Во второй половине брёрупского интерстадиала постепенно возрастает количество сосны $(50-60 \%)$, ели (до $30 \%)$ и крушины $(10-50 \%)$. В составе трав значительного развития достигают вересковые. Пыльцы ольхи и лещины мало, широколиственные породы представлены только единичными пыльцевыми зернами.

Наибольшее количество переотложенной пыльцы широколиственных пород обнаружено в глинистых сапропелях, которые образовались во время похолодания между эмским межледниковьем и брёрупским межстадиалом. Эти переотложенные пыльцевые зерна термофильных пород и послужили К. Иессену и В. Мильтерсу (Jessen, Milthers, 1928) поводом для выделения второго климатического оптимума эмского межледниковья (Andersen, 1961).

Как видно, спорово-пыльцевые спектры карукюласких межледниковых отложений не имеют ничего общего со спектрами брёрупского межстадиала и, следовательно, карукюлаские и брёрупские отложения не могут быть одновозрастными.

Кроме того, карукюлаские межледниковые отложения не могут быть сопоставлены верхневолжским интерстадиалом начала валдайского оледенения, который считается стратиграфическим аналогом брёрупского интерстадиала на Русской равнине. Верхневолжское потепление было кратковременным. По палинологическим данным оно характеризуется распространением таежных элементов - сосны (около 30-60\%) и ели $(15-30 \%)$, одновременно с которыми встречаются Betula nana L. $(10-25 \%)$ и травянистые растения (Гричук, 1961; Малаховский и др., 1969).

Карукюлаские органогенные отложения коррелируют по радиоуглеродным данным еще со многими интерстадиальными отложениями. Так, отложения Гражданского проспекта Ленинграда, характеризующиеся 
абсолютными датировками 39-40 тыс. лет, считаются одновозрастными с карукюласкими (Заррина, 1970, 1971).

Однако спорово-пыльцевые спектры отложений Гражданского проспекта свидетельствуют о существовании ледниковых условий (Спиридонова, 1970; Малаховский и др., 1969). Встречено много пыльцы травянистых растений $(20-40 \%)$, представленных преимущественно осоками и полынями, несколько меньше злаковых и лебедовых. Единичными зернами отмечена пыльца эфедры. Количество пылыцы Betula nana L. колеблется в пределах 10-60\%. Пыльца широколиственных пород практически отсутствует; обнаруженные единичные зерна последних, по всей вероятности, переотложены, так как наиболее частые находки их согпадают с максимумом карликовых берез.

По этим же причинам невозможно сопоставление карукюласких слоев и с другими разрезами более отдаленных районов, спорово-пыльцевые спектры которых свидетельствуют о существовании ледниковых условий. Так, разрезы Шестихино и Шенское Ярославской области, а также раз. рез Кашин Калининской области по датировкам абсолютного возраста (около 30-49 тыс. лет) считаются средневалдайскими и одновозрастными с карукюласкими органогенными отложениями (Заррина, 1971). Но в составе спорово-пыльцевых спектров этих разрезов, явно принадлежащих к ледниковой эпохе, преобладают сосна и береза с большим количеством Betula nana L. Много пыльцы травянистых растений, которые представлены осоками, злаками, полынями и лебедовыми; отмечена также эфедра. Поэтому сопоставление подобных спорово-пыльцевых спектров с карукюласкими межледниковыми спектрами ничем не обосновано.

Севернее Ленинградской области, вблизи Петрозаводска, открыты пресноводные отложения, которые считаются аналогом карукюлаского разреза, но одновременно коррелируют также с верхневолжским и I йоненским интерстадиалами (Девятова, Старова, 1970). Общими признаками этих разрезов считается максимум ели и присутствие широколиственных пород. Такие спорово-пыльцевые спектры свидетельствуют о кратковременном потеплении, что хорошо согласуется с названными интерстадиальными потеплениями, а также с теплым интервалом последнего оледенения около Петрозаводска. Қарукюлаские диаграммы свидетельствуют о развитии межледниковой растительности в течение более длительного времени.

Широколиственные породы в разрезе Карукюла кульминируют не одновременно, а в определенной последовательности - раньше других появляется вяз, потом кульминирует липа и затем граб.

По-особенному проявляет себя и ель. В карукюласких слоях пыльца ели встречается не только во время климатического оптимума - максимальное количество ее обнаружено преимущественно в слоях, образовавшихся до и после оптимальных климатических условий.

Состав широколиственных пород в разрезе Карукюла также несколько отличен - преобладающей здесь является липа. В разрезе около Петрозаводска липа совершенно отсутствует - широколиственные породы представлены только дубом и вязом.

Поэтому корреляция карукюласких межледниковых отложений с отложениями теплого интервала около Петрозаводска по спорово-пыльцевым данным не является вполне убедительной, тем более, что микулинские межледниковые отложения в Эстонии и Карелии хорошо коррелируют по пыльцевым зонам. 
Трудно согласиться также с корреляцией тосненского интерстадиала с карукюласким разрезом (Малаховский и др., 1969; Спиридонова, 1970). Тосненские слои около Ленинграда содержат сравнительно много пыльцы широколиственных пород (дуба, вяза, граба до 15\%). Поэтому если эту пыльцу считать первично залегающей, то тосненские слои должны считаться межледниковыми. Однако отсутствие закономерностей в появлении и кульминации названных термофильных пород, особенно; в составе спорово-пыльцевых спектров аллювиальных песков, в данном случае заставляет сомневаться в коренном залегании этих пыльцевых зерен и спор. Кроме того, состав спорово-пыльцевых спектров тосненских слоев - сравнительно высокое содержание лещины (44\%) и почти полное отсутствие липы - отличает их от карукюласких спектров и сближает с микулинскими или переотложенными микулинскими спорово-пыльцевыми спектрами.

Как видно, сопоставление карукюласких слоев по радиоуглеродным датировкам с вышеприведенными разрезами не подтверждается палинологическими данными.

Трудно объяснить, конечно, такое несогласие между палинологическими и радиоуглеродными данными. Может быть, это связано с тем, что сами радиоуглеродные датировки противоречивы. Так, например, остатки древесины в древесном торфе разреза Карукюла характеризуются весьма различными датировками - от 33 до $\geqslant 52$ тыс. лет (Каяк и др., 1970; Малаховский и др., 1969). Одннаково датирован пока только хвощовый торф - $48100 \pm 1650$ (ТА-101) и $48800 \pm 1200$ (ТА-277) лет (Каяк и др., 1971). Залегающие под торфом сапропелиты, к сожалению, не имеют еще конечных датировок; полученная для них оценка $-\geqslant 45000$ лет.

Имеющиеся расхождения в датировках отдельных слоев заставляют осторожнее относиться к абсолютным возрастам в этом опорном разрезе.

Опираясь на палеоботанические материалы, имеющие существенное значение при определении стратиграфического ранга, можно заключить, что карукюлаские отложения являются межледниковыми и могут быть сравнены только с типично межледниковыми отложениями.

Поэтому далее карукюлаские спорово-пыльцевые спектры будем сравнивать со спектрами других известных межледниковых горизонтов.

Микулинские спорово-пыльцевые спектры ясно отличаются от карукюласких, на что обратил внимание в своей рукописи уже К. Орвику (1941). Они свидетельствуют о существовании растительности, резко дифференцированной во времени: сперва существовали породы ксерофильного характера, потом - мезофильного (Гричук, 1961; Гричук и др., 1961). По карукюласким спорово-пыльцевым спектрам нельзя заключить о такой резкой дифференциации флоры; наиболее ксерофильные породы здесь представлены очень скромно - преобладающими являются породы мезофильного характера.

Флора одинцовского межледниковья имеет еще более ксерофильный характер и не может быть одновременной с карукюлаской.

Наиболее мезофильным характером отличаются флоры лихвинского и второго позднеплейстоценового межледниковий.

Второе позднепліейстоценовое межледниковье, соответствующее стратиграфически мологошекснинскому межледниковью А. Москвитина, характеризуется следующими пыльцевыми зонами по В. Гричуку (1961):

$\mathrm{N}_{6}$ - зона сосны с елью;

$\mathrm{N}_{5}$ - зона ели;

$\mathrm{N}_{4}$ - зона липы;

$\mathrm{N}_{3}$ - зона сосны с дубом;

$\mathrm{N}_{2}$ - зона сосны и березы;

$\mathrm{N}_{1}$ - зона ели. 
Благодаря высокому содержанию липы карукюлаские пыльцевые зоны III и $\mathrm{K}_{3}$ имеют сходство с зоной $\mathrm{N}_{4}$ второго позднеплейстоценового межледниковья, но отличаются от нее кривой ели. В Карукюла ель появляется в конце зоны березы и сосны (зона I), достигает своего максимума вместе с ольхой уже до климатического оптимума в зоне II, продолжает встречаться еще в большом количестве во время оптимальных климатических условий (зоны III, $\mathrm{K}_{3}$ ) и вновь кульминирует во второй половине межледниковья (зоны IV, $\mathrm{K}_{4}$ ). В то же время спорово-пыльцевые спектры второго позднеплейстоценового межледниковья характеризуются кратковременным ранним максимумом ели (зона $\mathrm{N}_{1}$ ), за которым следует сильное отступание ели и широкое распространение сосны с березой (зона $\left.\mathrm{N}_{2}\right)$. В климатическом оптимуме ели по-прежнему мало $\left(\mathrm{N}_{3}\right.$, $\mathrm{N}_{4}$ ). Отличительным признаком карукюлаской флоры является распространение граба и присутствие пихты (зоны III, IV), которые не считаются характерными для второго позднеплейстоценового межледниковья.

Лихвинские флоры характеризуются следующими пыльцевыми зонами по В. Гричуку (1961):

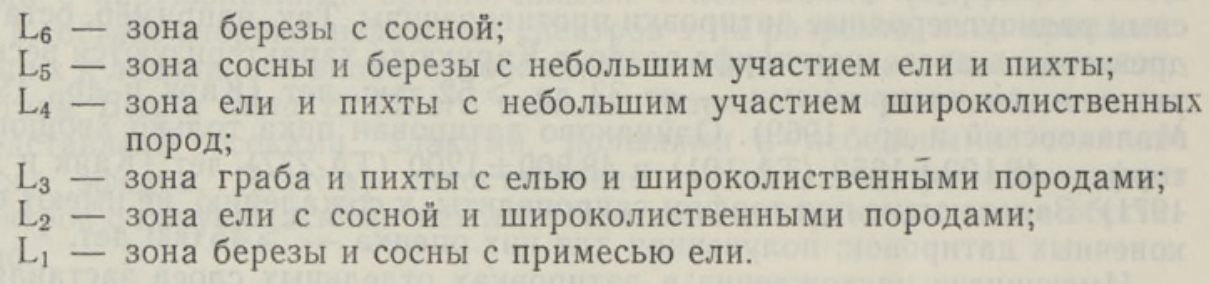

Закономерности распространения ели в межледниковое время в Карукюла те же, что и в лихвинском межледниковье. Ель появляется в зоне сосны и березы $\left(\mathrm{L}_{1}, \mathrm{I}\right)$, кульминирует вместе с ольхой до климатического оптимума (зоны $\left.\mathrm{L}_{2}, \mathrm{II}\right)$, продолжает встречаться в большом количестве в климатическом оптимуме (зоны $\left.\mathrm{L}_{3}, \mathrm{III}, \mathrm{K}_{3}\right)$ и достигает своего максимума опять после оптимальных климатических условий (зоны $\mathrm{L}_{4}, \mathrm{IV}, \mathrm{K}_{4}$ ). Участие лещины по сравнению с ольхой очень незначительно как в лихвинских, так и в карукюласких межледниковых отложениях. Отличительным признаком карукюласких отложений является меньшее содержание граб́а и пихты и большее количество липы (зоны $\mathrm{L}_{3}, \mathrm{~L}_{4}, \mathrm{III}, \mathrm{IV}$ ).

Опираясь на приведенные выше признаки сходств и различий пыльцевых зон, карукюлаские спорово-пыльцевые диаграммы, по мнению автора, имеют наибольшее сходство с лихвинскими диаграммами.

О лихвинском возрасте карукюласких отложений писал уже И. Даниланс (1966), изучавший пульверниекские (лихвинские) межледниковые отложения в районе Летижа на территории Латвии.

Спорово-пыльцевые спектры пульверниекских межледниковых отложений, также как лихвинских и карукюласких, свидетельствуют о широком распространении хвойных пород на протяжении всего межледниковья, о раннем появлении ели и ольхи в первой половине межледниковья и очень незначительном участии лещины. Отличительным признаком пульверниекских отложений по сравнению с карукюласкими является большее содержание пихты и меньшее участие липы.

K сожалению, в пульверниекских отложениях пока не установлен видовой состав пыльцы и спор, что имеет существенное значение при определении возраста по палеоботаническим данным. Видовые определения очень важны в тех случаях, когда в пыльцевых зонах наблю- 
даются какие-либо отклонения от общих закономерностей типовых разрезов.

Поэтому очень важно уточнить видовой состав пыльцы и спор в карукюласких и особенно пульверниекских отложениях, чтобы решить вопрос о возрасте этих двух, относительно близко расположенных межледниковых разрезов, имеющих существенное значение в стратиграфии плейстоценовых отложений Прибалтики.

По геологическим данным карукюлаские органогенные слои, залегающие под одной мореной последнего оледенения, считаются позднеплейстоценовыми и находящимися в коренном залегании (Орвику, 1960; Орвику, Пиррус, 1965; Пуннинг и др,. 1967; Раукас и др., 1968; Серебрянный и др., 1969).

В последнее время в результате бурения выяснилось, что карукюлаские органогенные отложения расположены на склоне древней погребенной долины, заполненной моренами и разделяющими их водноледниковыми отложениями. Моренные горизонты в погребенной долине условно отнесены к московскому ранневалдайскому (серая морена) и днепровскому (коричневая морена) оледенениям (Каяк и др., 1971).

Известно, что более древние отложения могли быть переотложены вновь наступающими ледниками. Поэтому наиболее вероятно, что именно самые молодые отложения (в том числе и межледниковые) должны встречаться в наибольшем количестве. Следовательно, находки отложений второго позднеплейстоценового межледниковья должны быть более частыми по сравнению с находками микулинских и лихвинских отложений. Но, как ни странно, карукюлаские слои являются пока единственными межледниковыми отложениями на территории Прибалтики, которые относятся к самому молодому межледниковью.

Радиоуглеродные данные указывают на позднеплейстоценовый возраст карукюласких отложений, но на основании этих же данных карукюлаские межледниковые отложения попадают в один интервал с разрезами явно интерстадиальных отложений.

Следовательно, карукюлаский разрез таит еще много нерешенных проблем. В настоящее время можно с полной уверенностью сказать только одно, что карукюлаские органогенные отложения являются бесспорно межледниковыми и имеют по палинологическим данным большое сходство с отложениями лихвинского межледниковья, а также второго позднеплейстоценового межледниковья.

\section{ЛИТ Т РА Т У Р А}

В а й т екун а с П. П. 1969. К истории накопления материала о ледниковых отложениях Прнбалтики и основным этапам его обобщения. В сб.: Материковое оледенение и ледниковый морфогенез. Вильнюс.

В игдорчнк М. Е., Ауслендер В. Г., Долуханов П. М., 3 на менская О. М., Г ай геров а Л. А., Агр а о в а Д. М., Ге й В. П. 1970. Геохронологическое и ритмостратиграфическое расчленение плейстоцена северо-запада Русской равнины. В сб.: Периодизация и геохронология плейстоцена. Л.

Г р и ч ук В. П. 1961. Ископаемые флоры как палеонтологическая основа стратиграфии четвертичных отложений. В кн.: Рельеф и стратиграфия четвертичных отложений северо-запада Русской равнины. М.

Гри ч ук В. П. 1969. Значение палеоботанических материалов для стратиграфии валдайских отложений. В кн.: Последний ледниковый покров на северо-западе Европейской части СССР. $M$.

Д а н и л ан с И. Я. 1966. Пыльцевые зоны миндель-рисских отложений бассейна р. Летижа и их сопоставление с аналогичными зонами в других районах. В сб.: Палинология в геологических исследованиях Прибалтики. Рига. 
Д евятов а Э. И., С т а р в а Н. Н. 1970. Верхнечетвертичная история Онежской и Ладожской котловин по данным спорово-пыльцевого и диатомового анализов. В сб.: История озер, Тр. Всес. симп., Н. Вильнюс.

3 а р р и н Е. П. 1970. Геохронология и палеогеография позднего плейстоцена на северозападе Русской равнины. В сб.: Периодизация и геохронология плейстоцена. Л.

3 а р рин а Е. П. 1971. Стратиграфия и геохронология позднего плейстоцена северозапада Европейской части СССР. Автореф. дисс. канд. геол.-мин. н.

К а я к К., П ун н и н Я Я.-М., Р а у к а с А. 1970. Новые данные о геологии разреза Карукюла. Изв. АН ЭССР, Хим. Геол., 19, № 4.

К ессел Х. Я. 1963. Голоценовые береговые образования на юго-западном побережье Эстонии. Тр. Ин-та геол. АН ЭССР. XII.

Малаховский Д. Б., Спиридонова Е. А., Котлукова И. В., Баканов а И. П., Б у с ло в и ч А. Л., К в а с о в Д. Д. 1969. Валдайский горизонт. В кн.: Геоморфология и четвертичные отложения северо-запада Европейской части СССР. Л.

О р в и ку К. К. 1960. Четвертичная система (антропогеновые отложения). В кн.: Геология СССР, XVIII, Эстонская ССР. М.

О р в и ку К. К., Пं и р р у с Р. О. 1965. Межморенные органогенные отложения в Карукюла (Эстонская ССР). В сб.: Литология и стратиграфия четвертичных отложений Эстонии. Таллин.

Пи р р у с Р. О. 1963. История развития верхового болота Нигула. Тр. Ин-та геол. АН ЭССP, XII.

П унн и нг Я.-М., И ль в е с Э., Л и й в А. 1966. Датирование древних образцов радиоуглеродным методом. Изв. АН ЭССР, Сер. биол., 15, № 4.

Пуннинг Я.-М. К., Р аука с А. В., С еребрянный Л. Р. 1967. Геохронология последнего оледенения Русской равнины в свете новых радиоуглеродных датировок ископаемых озерно-болотных отложений Прибалтики. Мат-лы II симп. по истории озер северо-запада СССР. Минск.

Пуннинг Я.-М. К., Р а ука с А. В., Серебрянный Л. Р. 1969. Карукюлаские межледниковые отложения Русской равнины. Изв. АН ЭССР, Сер. геол., № 10.

Р а у к а с А. В., С ер еб р ян н ыи Л. Р., П ун н и г Я.-М. К. 1968. Об абсолютном возрасте краевых зон и эволюции оледенения на северо-западе Русской равнины в позднем плейстоцене. Тезисы докл. Всес. межведомств. совещ. по изучению краевых образований материкового оледенения. Смоленск.

С ер еб рян н ы й Л. Р., Р а у к а с А. В., П ун н и н Я Я.-М. К. 1969. К истории развития оледенения на северо-западе Русской равнины в верхнем плейстоцене. Мат-лы глящиолог. исслед., хроника, обсуждения, 15. М.

С п и и д о о в а Е. А. 1970. Палинологическая характеристика межстадиальных отложений валдайского оледенения на северо-западе Русской равнины и ее значение для стратиграфии и палеогеографин. Автореф. дисс. канд. геогр. н.

\section{Ннститут геологии \\ Академии наук Эстонской ССР}

Поступила в редакцию

$18 / \mathrm{I} 1972$

\section{ELSBET LIIVRAND}

\section{KARUKULA JÄ̈̈VAHEAEGSETE SETETE PALUNOLOOGILINE ISELOOMUSTUS JA KORRELATSIOON}

Karuküla organogeensete setete õietolmuspektrite võrdlemisel holotseensetega tehti k.indlaks, et nad pärinevad jäävaheajast.

Nende setete stratigraafilise asendi määramine on raske. ${ }^{14} \mathrm{C}$-dateeringute põhjal satuvad Karuküla jäävaheaegsed setted ühte vanuselisse intervalli paljude valdai jäätumisaegsete interstadiaalsete setetega, milliseid palünoloogiliste andmete pōhjal pole võimalik omavahel rööbistada. Neid võib võrrelda ainult jäävaheaegsete setetega ja seepärast ei saa neid korreleerida ka brörupi ja ülemvolga interstadiaalsete setetega. Pärna öietolmu suure sisalduse tôttu meenutavad Karuküla spektrid teist hilispleistotseenset jäävaheaega, kuid kōige suurem sarnasus on neil siiski lihvini õietolmuspektritega. Neid iseloomustab suur okaspuude öietolmu sisaldus kogu jäävaheaja vältel, varajane kuuse ja lepa ilmumine, kuuse maksimum vahetult enne klimaatilist optimumi, rohke esinemine ka kõige soojemal ajal ja uus maksimum pärast kliimaoptimumi, samuti valgepöögi ja nulu esinemine jäävaheaja teisel poolel; iseloomulik on ka sarapuu väga tagasihoidlik esinemine lepaga võrreldes. 


\section{ELSBET LIIVRAND}

\section{DIE PALYNOLOGISCHE CHARAKTERISTIK UND KORRELATION DER INTERGLAZIALABLAGERUNGEN DES PROFILS VON KARUKOLA}

Auf Grund eines Vergleichs der Pollendiagramme von Karuküla mit holozänen Diagrammen ist festgestellt worden, daß die organischen Ablagerungen des Profils von Karuküla aus einer Interglazialzeit stammen. Eine genauere Bestimmung der stratigraphischen Zugehörigkeit dieser Ablagerungen fällt schwer. Nach den $C^{14}$-Datierungen geraten sie ins gleiche Altersintervall mit vielen Interstadialablagerungen der Waldaieiszeit. Die palynologischen Angaben ermöglichen es nicht, eine solche Korrelation durchzuführen. Die organischen Ablagerungen von Karuküla gehören unbestreitbar zur Interglazialzeit und können nur mit Interglazialablagerungen korreliert werden. Eine große Menge von Lindepollen erinnert an die zweite Interglazialzeit des Spätpleistozäns von W. Gritschuk, aber die größte Ahnlichkeit haben die Pollendiagramme von Karuküla mit den Pollendiagrammen der Lichwin-Interglazialzeit. Sie zeigen eine ausgedehnte Verbreitung von Nadelbäumen, ein früheres Erscheinen der Fichte und der Erle, ein Fichtenmaximum unmittelbar vor dem Klimaoptimum, eine große Fichtenmenge auch während der wärmsten Zeit und ein neues Fichtenmaximum nach dem Klimaoptimum. Die Pollendiagramme von Karuküla zeigen noch eine Ausbreitung der Tanne und der Weißbuche während der oberen Hälfte der Interglazialzeit und die große Häufigkeit der Erle im Vergleich zur Hasel, 